\title{
Working
}

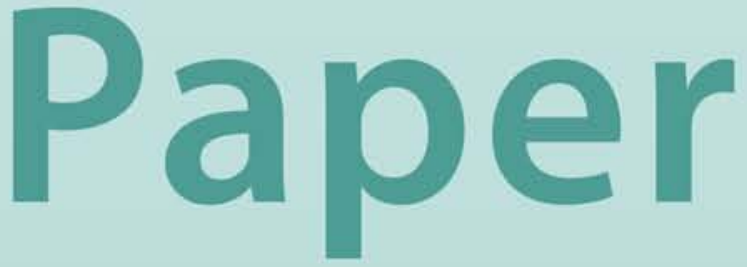


Philippines: Preparations for Inflation Targeting

Piyabha Kongsamut 


\title{
IMF Working Paper
}

Asia and Pacific Department

\section{Philippines: Preparations for Inflation Targeting}

\author{
Prepared by Piyabha Kongsamut ${ }^{1}$ \\ Authorized for distribution by Joshua Felman
}

August 2001

\begin{abstract}
The views expressed in this Working Paper are those of the author(s) and do not necessarily represent those of the IMF or IMF policy. Working Papers describe research in progress by the author(s) and are published to elicit comments and to further debate.
\end{abstract}

The Philippines is planning to shift toward adoption of an inflation targeting framework in 2001. This paper reviews key policy issues in this context, describes various operational and technical preparations, and presents an empirical analysis of the factors driving inflation. Among the key policy requirements, while central bank independence appears assured, the exchange rate has been allowed to fluctuate largely freely, and the authorities are embarking on a medium-term plan for fiscal consolidation. Empirical results suggest that the effective exchange rate (rather than a bilateral rate) and wages are important long-run influences on inflation.

JEL Classification Numbers:C22, C32, E31, E37, E52

Keywords: Philippines, inflation targeting, inflation modeling

Author's E-Mail Address:pkongsamut@imf.org

\footnotetext{
${ }^{1}$ Piyabha Kongsamut is an economist in the Asia and Pacific Department. I thank Bas Bakker, Ray Brooks, Nigel Chalk, Joshua Felman, and Markus Rodlauer for valuable comments. Ioana Hussiada provided invaluable research assistance.
} 


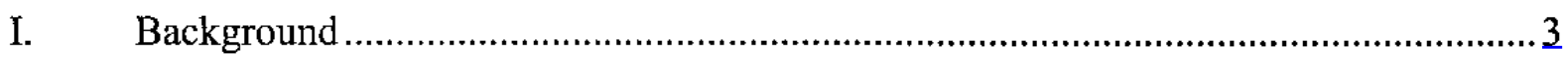

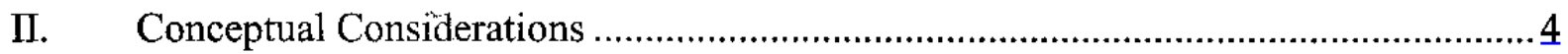

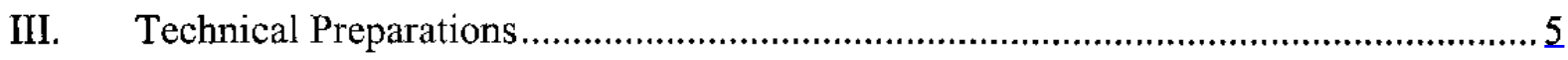

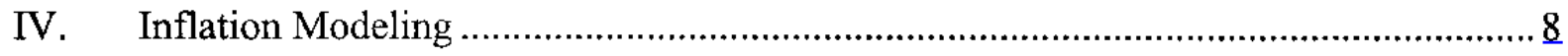

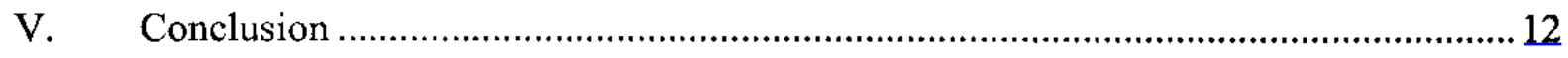

References

Tables

1. Long-Run Results with Nonfood Consumer Price Index........................................14

2. Long-Run Results with Nonfood Consumer Price Index......................................14

3. Error-Correction Models Using Equation 4a as Long-Run Relation .........................15

\section{Figures}

1. Quarterly Food Inflation Annualized, 1982-2000 …..........................................

2. Exchange Rate Measures, 1995-2000 ………….................................................. 10

Appendix

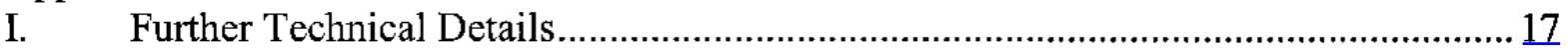

Annex

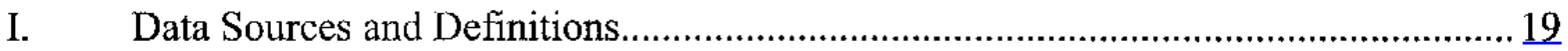




\section{PREPARATIONS FOR INFLATION TARGETING}

1. In early 2000, the Bangko Sentral ng Pilipinas (BSP) decided to shift to inflation targeting as its monetary policy framework. The shift is to take place by late-2001, with the period until then devoted to the necessary preparations, including on the operational details of the framework, inflation forecasting models, and public education regarding the change. Inflation targeting would incorporate many elements of the BSP's approach to conducting monetary policy in recent years, aiming for price stability, but taking into account also other factors such as output growth and exchange rate. It would, however, subsume these elements into a consistent framework with inflation as the dominant medium-term objective. In addition, the new framework will enhance accountability and transparency of the central bank, and lead to better public understanding of the objectives and actions of the BSP.

2. While the BSP has made significant progress with preparing for inflation targeting, some important actions are still needed to make it successful. This paper first reviews some key policy issues in the context of the move to inflation targeting, then describes various operational and technical preparations, and presents an empirical analysis of the factors driving inflation before concluding.

\section{BACKGROUND}

3. Reforms over the past two decades have significantly strengthened the central bank and enhanced its ability to conduct monetary policy effectively. Before the creation of the BSP in 1993, the old central bank was burdened with financing a sizable fiscal deficit, bailing out troubled commercial banks, and channeling credit to priority sectors. Even so, since the early 1980 s, the instruments of monetary policy were being reformed, with interest rate controls and credit ceilings gradually lifted and replaced by more indirect instruments of policy (including open-market instruments and reserve requirements). Thus, with the necessary instruments already in place, when the independent BSP was established, it was well-equipped to effectively implement monetary policy.

4. In recent years, the BSP has responded flexibly to new challenges and maintained a clear focus on achieving macroeconomic stability; since the Asian crisis, it has gradually shifted toward inflation targeting. Important challenges included dealing with large capital inflows in the mid 1990s; the Asian crisis; and the period since the crisis including the most recent turbulence related to the political crisis. However, the BSP's actions have generally been lacking a clear and consistent policy framework, and at times it appeared that multiple objectives were being followed (for example, monetary policy since 1983 had been formally based on a base money targets and a floating exchange rate, but the peso was de-facto pegged to the U.S. dollar between late 1995 and July 1997). ${ }^{2}$ Over the past two years, policy has shifted

${ }^{2}$ See IMF Occasional Paper No. 187 for an account of the conduct of monetary policy since 1983. 
increasingly toward giving more weight to the inflation outlook, and the exchange rate of the peso has been broadly determined by market prices (though the BSP does intervene to smooth sharp fluctuations).

5. In late 2000, the BSP was confronted with the challenges of dealing with severe market turbulence in the events leading up to the removal of President Estrada. This experience raises the question of how to conduct inflation targeting during periods of such turbulence (in particular, how to react to a massive loss of confidence and pressure on the peso).

6. Besides the turbulence in the financial markets, the recent fiscal deficits also complicate the effective conduct of monetary policy. Fiscal slippages over the past two years have raised the domestic financing requirement of the budget, and unless contained, may create pressure for monetization, worsening the tradeoffs faced by the BSP and increasing the risk it might have to provide direct credit to the government. ${ }^{3}$

\section{Conceptual Considerations}

7. Among the key policy requirements for inflation targeting, central bank independence appears reasonably well assured, the exchange rate has been allowed to fluctuate largely freely, and the authorities are embarking on a medium-term plan of fiscal consolidation.

- As noted above, the BSP was created as an independent entity in 1993, with a clear mandate to "maintain price stability conducive to the balanced and sustained growth of the economy." The BSP has legal and de facto control over the monetary policy instruments needed to achieve its targets.

- Fiscal consolidation is needed to support achievement of the inflation target. The size of the budget deficit in 2001, and the limited access to market financing from abroad during this period, imply a large domestic financing requirement. Continued large financing requirements would raise the pressure for monetization and imply the loss in dominance of the inflation target. The authorities have taken various initiatives to control the deficit (including improvements in tax administration and spending restraints), and plan for fiscal consolidation over the medium-term.

- Continued exchange rate flexibility is needed to ensure dominance of the inflation target. Over the past year, the BSP has given more weight to the inflation outlook in

${ }^{3}$ The BSP is not currently providing any direct credit to the National Government (NG). The BSP Act of 1993 closed the door to unlimited extension of central bank credit to the NG. Instead, it allows for emergency credits to be provided from the BSP to the NG, for a maximum of 6 months, not exceeding 20 percent of the average annual income of the last three preceding fiscal years. 
implementing interest rate policy. In addition, the approach taken in October 2000 was calibrated to limit the inflationary consequences of depreciation, and appropriately focused on the medium-term objective.

8. Besides efforts to ensure the dominance of the inflation target, some other reforms would strengthen the chances of success of the new inflation targeting framework. Financial sector reforms to enhance the breadth and depth of markets would help soften the impact of shocks on the economy and strengthen the transmission mechanism of monetary policy. ${ }^{4}$ Moreover, liberalization of international trade in agricultural products would lessen the impact of weather-related shocks on inflation ${ }^{5}$. Currently, such shocks cause frequent spikes in food inflation, though their impact is short-lived (Figure 1). More liberalized trade in agricultural products would allow imports to take up the slack and reduce volatility in food prices.

\section{Technical Preparations}

9. The BSP is implementing intensive preparations for the formal shift to inflation targeting. Although final decisions are still to be made, a great deal of work has been done on operational details, inclucing the modalities of setting the target, the details of the target itself (point vs. range and tolerance interval, the target horizon, and any escape clauses), as well as

${ }^{4}$ A law proposing reforms in financial sector taxation is on the agenda. A real time gross settlement system has recently implemented, covering transactions in equities, fixed income, money and foreign exchange markets. In addition, the recently passed General Banking law will help create a more stable and healthier financial system, and will help ensure a more effective transmission of monetary policy.

${ }^{5}$ Trade liberalization in agricultural products would also have other benefits, such as spurring productivity growth in the sector. The authorities are continuing to implement a phased import tariff reduction program, and are taking steps toward liberalization of trade in basic agricultural products through reforms of the National Food Authority (under a legislative proposal to separate its regulatory functions from its market intervention functions). 
transparency and accountability measures. On the technical front, work is being done on inflation forecasting models for various time horizons and techniques, including a singleequation model, a VAR-based model, and a multi-sectoral macroeconometric model. The BSP expects to formally shift to the new framework by fall-2001.

\section{Operational Aspects}

10. The target will likely be jointly set by the Government and the BSP, to ensure consistency of macroeconomic policy and commitment of the government as a whole in achieving the inflation objective. Other countries have adopted varying approaches, from central banks unilaterally announcing targets, to joint announcements of the government and the central bank. In the Philippine context, macroeconomic targets have been announced historically by an inter-agency body, the Development Budget Coordinating Committee (DBCC), of which the BSP is a member. ${ }^{6}$ Under the current institutional arrangement, the National Economic and Development Authority (NEDA) is the lead agency in the setting of the inflation target. With the formal adoption and implementation of inflation targeting, the BSP is expected to play a more active role in the development of the inflation target. This is aimed at strengthening the mechanism for setting the inflation target as well as ensuring greater commitment of the Government as a whole in achieving the inflation objective.

11. Overall CPI inflation will probably be the ultimate target, although a narrower measure of inflation will also need to be closely monitored for policy purposes. Credibility considerations argue for adopting the headline CPI as the main target, rather than any alternative measure. However, given that food items comprise 51 percent of the overall basket, and are subject to weather-related shocks, a narrower definition of inflation should also be monitored closely as a gauge of underlying pressures. ${ }^{7}$ The authorities have constructed a working definition of core inflation which excludes large, unpredictably volatile items (five items, comprised of some unprocessed food categories, and fuel, accounting for around $1 / 4$ of the basket). In addition, the policy response to inflation from weather-related supply sources should be different from those originating in demand pressures; response to supply-side pressures should be muted, as experience suggests their impact is temporary, and action should only be taken to prevent second-round effects.

12. The announced tärget will likely be a point target, with a tolerance interval of \pm 1 percent, and a two-year target horizon over which the BSP would commit to achieving the targeted inflation rate. An explicit point target with the use of a tolerance interval would

${ }^{6}$ THE DBCC is composed of the Department of Budget and Management (DBM) as Chairman and the Department of Finance (DOF), NEDA, BSP, and the Office of the President as member.

${ }^{7}$ The National Statistics Office may begin to release core inflation statistics. The BSP also monitors other measures of core inflation, including the trimmed mean, weighted median, and inflation net of volatile items (including also other items besides food and oil). 
help focus the public's attention on the inflation target, while allowing for some flexibility in the conduct of monetary policy. A wider tolerance interval raised concerns of credibility, and was rejected. At the same time, the two-year target horizon would allow for sufficient scope for the BSP to respond to shocks and influence inflationary expectations.

13. The BSP is also considering the use of a number of escape clauses. These include:

- Significant government policy changes that directly affect prices

- Prices of oil products

- Prices of selected food items

- Natural disasters affecting the major part of the economy

These escape clauses are broadly in line with those in use by other inflation-targeting countries. At the same time, in case of any breach of target, the BSP plans to provide a full explanation to the public as to why the breach had occurred, what actions (or not) are being taken to bring inflation back within tolerance levels, when inflation is expected to be brought within range, as well as the path of inflation towards that range.

\section{Mechanisms for transparency and accountability}

14. One of the essential features for successful operation of inflation targeting is clear established mechanisms for transparency and public accountability. ${ }^{8}$ These take the form of regular public releases of information (e.g. an "inflation report"), including the central banks' views on inflation performance, the inflation outlook, and the motivations behind policy action (or inaction). In addition, any policy action taken between reports is accompanied by a press release explaining the change and factors behind the policy decision. Besides these reports, senior officials of some central banks also make regular presentations to various audiences in order to foster better understanding of the conduct of monetary policy and its objectives.

15. The Philippine authorities are considering adopting some of these mechanisms, including inflation reports, public release of BSP reports and minutes of Monetary Board meetings, as well as reports to Congress. Quarterly inflation reports are envisaged, as well as continuing the current practice of monthly commentaries on inflation developments and shortterm prospects. In addition, the authorities are considering releasing minutes of Monetary Board meetings on matters pertaining to analysis of the inflation process and other factors leading to the determination of the monetary policy stance. As for reporting requirements to Congress, the BSP currently makes annual reports during the budget cycle. Finally, the BSP plans to continue sponsoring seminars and conferences to discuss monetary developments and policy issues.

16. One of the accountability mechanisms being considered includes issuance of an open letter to the President in case of a breach of the inflation target. Such a letter would

${ }^{8}$ See IMF Occasional Paper No. 202. 
explain the sources of the deviation, measures to be adopted to bring the inflation path back within the tolerance interval, and the time path for these measures to take effect.

17. These measures are in line with those being used by other inflation-targeting countries, and should play an important role in enhancing the public's understanding of the conduct of monetary policy, as well as in ensuring the BSP's accountability.

\section{INFLATION MODELING}

18. Understanding the various factors influencing inflation is important for the success of inflation targeting. The changing economic environment in the 1990s, including financial liberalization and the Asian crisis have complicated the search for stable empirical relationships between monetary policy instruments and inflation. Also, the volatility of food prices has made estimation of an inflation equation difficult. Considerable work has been done in the past on modeling inflation in the Philippines, including by Debelle and Lim (1998) and Guinigundo (1999). This section builds on their work, but takes a different approach to modeling, as follows: (a) modeling non-food inflation, to eliminate the volatility introduced by including food prices (although fuel prices are still included in this basket; exclusion of fuel was limited by data availability); (b) seeking a long-run behavioral cointegrating relation between variables, while taking into account theoretical priors (see below); (c) including the impact of wages on inflation; and (d) testing the importance of various effective exchange rate measures, rather than focusing solely on the bilateral exchange rate against the U.S. dollar. A long-run behavioral relation is first estimated, followed by a short-run error-correction model which could be used for forecasting inflation (see next section).

\section{Long-Run Model}

19. As noted above, the nonfood portion of the CPI basket is modeled, as it should be more responsive to policy, and reflect underlying trends. The long-run relationship is estimated (using cointegration), based on a mark-up model along the lines of de Brouwer and Ericsson (1995), and can be characterized as:

$$
\mathrm{p}=\gamma \cdot \mathrm{ulc}+\delta_{1} \cdot \mathrm{e}+\delta_{2} \cdot \mathrm{p}^{*}
$$

where

$\mathrm{p} \quad=$ nonfood consumer price index

ulc = an index of the nominal cost of labor for each unit of output (unit labor cost), using minimum wage data ${ }^{9}$

e $\quad=$ the exchange rate (either bilateral or in effective terms)

\footnotetext{
${ }^{9}$ Annex I describes the sources and definitions of the variables in the equations. The sample begins in 1988, following significant reforms in monetary management and operations.
} 
p* = foreign prices (defined in various ways, to match the exchange rate measure being used, but operating through purchasing power parity, see below).

This approach will also allow a test for consistency with theoretical priors to be conducted, where the coefficients on the domestic and external forces should sum to one $\left(1=\gamma+\delta_{1}+\delta_{2}{ }^{10}\right)$. That is, doubling wage costs, the exchange rate and foreign prices should result in the price level doubling (later referred to as long-run homogeneity).

\section{Results indicate the existence of a long-run relation between the CPI (nonfood),} foreign prices, and unit labor costs, but the coefficients are not of sensible magnitudes (Table 1). Using the bilateral rate against the U.S. dollar does not yield a significant long-run relation, nor any theoretically sensible coefficients (Equation 1). ${ }^{11}$ When the nominal effective exchange rate index (with 1990 trade weights) is used instead of the bilateral exchange rate, long-run relations are found between the variables (Equation 2), with coefficients on the unit labor cost variable higher than expected, and the coefficient on foreign prices of the wrong sign. Equation $2 \mathrm{a}$ shows a further refinement on the nominal effective exchange rate, by adjusting the foreign price for import-tariffs. A significant long-run relation is found, but again with a coefficient on the unit labor cost which is too high.

21. If the effective exchange rate measure is based on more current trade weights, a more sensible result emerges ${ }^{12}$ (Table 2). Equations 3 and 4, using export-weighted and import-weighted effective exchange rates (1999-2000 trade weights), respectively, show reasonable magnitudes for the domestic and external factors, and tests for long-run homogeneity are not rejected (Equations $3 \mathrm{a}$ and $4 \mathrm{a}$ ). That is, the coefficients on the domestic and external factors sum to one (with the coefficients on the external factors restricted to be equal). A further refinement of adjusting for import-tariffs also shows sensible results, with long-run homogeneity not rejected (Equation 4b), though the coefficient on unit labor costs is quite high relative to previous equations.

22. In summary, the main results from the estimations are three-fold:

- A 10 percent depreciation of the nominal effective exchange rate will result in a $3 \frac{1}{2}$ percent increase in the non-food CPI (with all else unchanged) in the long run.

${ }^{10}$ In some cases below the effects of the exchange rate and foreign prices are restricted to be equal, or $\delta_{1}=\delta_{2}$.

11 This result is also likely to be influenced by the de facto exchange rate regime in place during this period, including a peg in the late 80 s to early 90s and again in late 1995-mid 1997.

12 Trade patterns have shifted somewhat over the past few years, with increasing intra-regional trade, and export and import trade patterns are quite different from each other. 
- A 10 percent increase in the unit labor costs will raise non-food prices by 6-8 percent in the long run (with all else unchanged).

- The above results, however, do not suggest anything about how long it will take for these effects to pass through. A short-run error correction model is required for this analysis (see below).

\section{The policy implications are two-fold:}

- $\quad$ More attention should be given to the influence of the effective exchange rate on inflation, rather than the exchange rate against the U.S. dollar. Exchange rate movements in 2000 confirm that the nominal effective exchange rate (import weighted) was much less depreciated than the bilateral rate against the U.S. dollar (Figure 2), and suggests less cause for concern on the inflationary impact of the depreciation.

- Wage considerations also play an

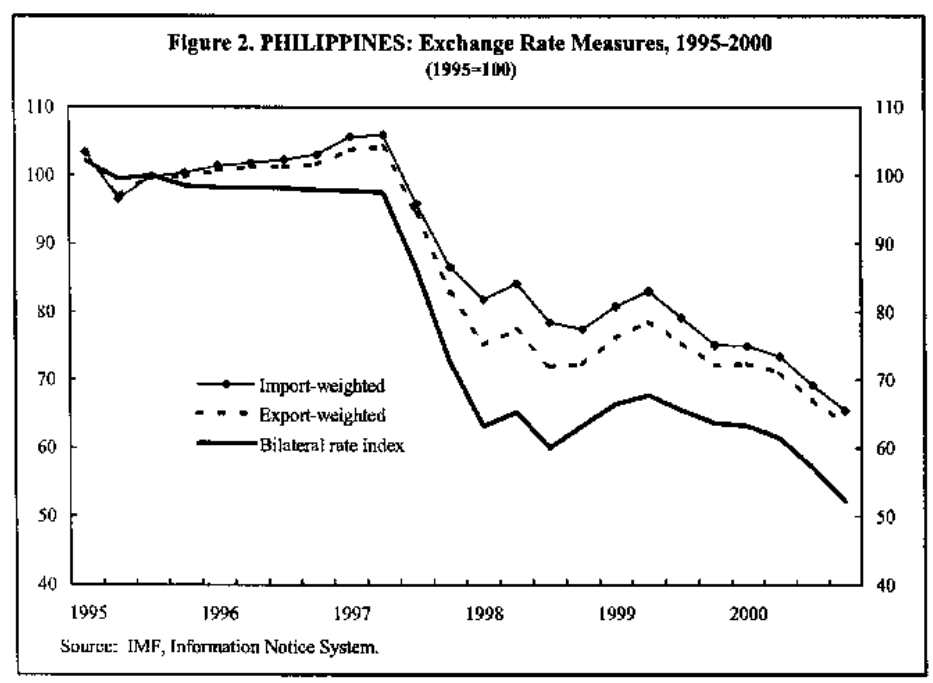
important role in determining inflation. Hence, negotiations on the minimum wage should carefully take into account the estimated impact on inflation, especially given the shift to inflation targeting. In addition, efforts should be made to carefully monitor wage movement and improve wage data. ${ }^{13}$

\section{Similar estimations using the overall CPI rather than the nonfood CPI as the} dependent variable do not yield satisfactory results (see Appendix I). In these cases, the coefficients in the various equations do not look reasonable (particularly the impact of foreign prices), and they are far away from linear homogeneity. It appears that the frequency and magnitude of shocks to food prices preclude finding any sensible long-run relationships.

25. While these results seem to call into question the appropriateness of the overall CPI as the target, they do not preclude this choice. By choosing the overall index, a concept with which the public is familiar, the BSP's credibility will be enhanced. The cost, however, may be that the target may be missed when food prices respond more to agricultural performance than to monetary policy. In this context, the BSP's commitment to transparently explain its monetary

${ }^{13}$ Broader wage survey data is available, but some improvements in measurement (including adjusting for quality of work) are needed. 
policy actions will help foster the public's understanding of the issues. As the inflation targeting framework develops, the public will come to better understand the reasons for BSP inaction in the case of first-round effects of temporary price shocks (including those originating from food).

\section{Short-Run Equation (Error-Correction Model of Inflation)}

26. A number of error-correction models were also estimated to build on the above analysis and provide a basis for forecasting inflation over the short-term. Table 3 presents error-correction models based on the long-run relation using Equation 4a from Table 2, which includes the nonfood price index, the unit labor cost, the import-weighted nominal effective exchange rate index, and the import-weighted foreign price index. ${ }^{14}$ The short-run model, besides including the differcnces of the variables in the long-run equation, also allows for the impact of other influences, including the (non-agricultural) output gap, domestic oil prices, and monetary policy variables (captured by reserve money, interest rates, or a broader money aggregate). A general-to-specific approach to model reduction is taken, with lags of all the variables included, and non-significant variables progressively eliminated.

\section{Key results from the error-correction model include the following:}

- The error-correction term is stable across equations and significant, with a coefficient of around -0.21 to -0.23 , indicating that in the next quarter after a shock to the long-run relation, non-food prices adjust by over 20 percent back to the equilibrium. The coefficient implies that it would take around 5 quarters for nonfood prices to fully adjust to shocks to unit labor costs, the nominal effective exchange rate, and foreign prices.

- On the effective exchange rate, results indicate that the short-run effect of a disturbance in the exchange rate would affect inflation directly for two quarters after the shock (with a 10 percent depreciation in the exchange rate eventually leading to a 2 percent increase in inflation), but the return to long-run equilibrium would take 5 quarters (as noted above).

- On the unit labor cost, the results are somewhat mixed; the contemporaneous coefficient indicates a positive relation, but the second and third lags carry negative coefficients ${ }^{15}$.

\footnotetext{
${ }^{14}$ The focus on the import-weighted effective exchange rate, besides making economic sense, also stems from tests on the time-series properties of the import-weighted exchange rate and foreign prices yielding more conclusive results than those on the alternatives (see the Appendix I for results of the tests on the time-series properties).

${ }^{15}$ Simultaneous variables are included for the variables in the long-run relation, based on the results of weak exogeneity tests which were not rejected for the unrestricted model (see Appendix I). In addition, tests for parameter constancy show that coefficient estimates are stable for most of the sample.
} 
- A 100 percent increase in oil prices would result in a $2 \frac{1}{2}$ percentage point increase in nonfood inflation in the following quarter.

- The coefficient on the non-agricultural output gap is only weakly significant (Equation 1), and when more lags are included it remains marginally significant and also switches sign (Equations 2 and 3). This result seems to indicate that demand pressures have not been a significant factor in determining inflation during this period.

- $\quad$ Monetary policy variables (reserve money, and interest rates) do not enter significantly into the model (Equations 2 and 3), thus the model gives little insight into the transmission mechanism and lags of monetary policy. It is possible that the interest rate variable is not significant if its impact is mainly channeled through the exchange rate; this channel should be investigated in future work. ${ }^{16}$

- Preliminary alternative attempts to estimate the transmission mechanism have not been successful. Vector autoregression results found that shocks to monetary policy variables generated responses in the opposite direction from expected. ${ }^{17}$

- Diagnostic tests are satisfactory. Tests on the residuals are satisfactory, but tests for the stability of the coefficients show a problem at the end of the sample, when the model predicts much higher inflation in 2000 than actually occurred.

28. While the results of the estimation are encouraging, the monetary policy transmission mechanism remains to be identified, and a wide range of inputs will likely be needed as a guide to policy. Inflation forecasts should be guided by a combination of indicator variables, quantitative economic models, and qualitative judgment. Each of these components contain different information that will all be useful in coming to a view on the inflation outlook for the economy, and the appropriate stance for monetary policy.

\section{Conclusion}

29. The BSP has been considerably strengthened and has become operationally independent, and progress is being made to ensure dominance of the inflation target. In particular, the exchange rate has become more flexible, and fiscal consolidation has been given high priority. Reforms that will broaden and deepen financial markets are in train, thereby strengthening the transmission mechanism of monetary policy; also, steps are being taken to

\footnotetext{
${ }^{16}$ In addition as the restricted long-run equation does not satisfy weak exogeneity (see Appendix I), a simultaneous equation model including the effective exchange rate as endogenous could also be investigated in future work.

${ }^{17}$ For example, a shock to the interest rate generated a further depreciation of the exchange rate in the impulse response functions.
} 
further liberalize the agricultural sector, helping to reduce volatility of food prices (and the overall CPI) as the impact of supply shocks is softened through international trade.

30. The BSP has made significant progress in preparing for inflation targeting. Operational details are being pinned down, including the setting of the target, the details of the target, as well as transparency and accountability measures. Technical work on inflation forecasting is proceeding.

31. Empirical results suggest that the import-weighted effective exchange rate and wages are important long-run influences on inflation in the Philippines. Thus, policymakers should focus more on effective exchange rate measures than on bilateral exchange rates in gauging the impact of exchange rate movements on inflation, and negotiations on the minimum wage should carefully take into account the estimated impact on inflation. 
Table 1: Long-Run Results with Nonfood Consumer Price Index

\begin{tabular}{|c|c|c|c|c|}
\hline & Estimated Cointegrating Vector & Lags & $\begin{array}{l}\text { Maximum } \\
\text { eigenvalue } \\
\text { test } 1 /\end{array}$ & Trace Test $1 /$ \\
\hline Sample period & 1988:Q1-2000:Q2 & & & \\
\hline \multicolumn{5}{|l|}{ Exchange rate measure used: } \\
\hline 1. Bilateral exchange rate, US\$ & $\mathrm{P}=0.38 \mathrm{ulc}+0.33 \mathrm{e}+1.29 \mathrm{p}^{*}$ & 4 & 20.54 & 46.28 \\
\hline 2. NEER & $\mathrm{P}=0.96 \mathrm{ulc}+0.38 \mathrm{e}-0.09 \mathrm{p}^{*}$ & 4 & $28.22^{*}$ & $51.65^{*}$ \\
\hline 2a. NEER, tariff-adjusted & $\mathrm{P}=1.07 \mathrm{ulc}+0.19\left(\mathrm{e}+\mathrm{p}^{*}(1+\mathrm{t})\right)$ & 3 & $21.77^{*}$ & $30.49^{*}$ \\
\hline \multicolumn{5}{|c|}{$\begin{array}{l}1 / *=\text { significant at the } 5 \text { percent level. } * *=\text { significant at the } 1 \text { percent level. } \\
2 / \text { Test statistic displayed in the maximum eigenvalue test column is the likelihood-ratio }\left(\chi^{2}\right) \text { test of the } \\
\text { null hypothesis that the restriction holds. }\end{array}$} \\
\hline & Estimated Cointegrating Vector & Lags & $\begin{array}{l}\text { Maximum } \\
\text { Eigenvalue } \\
\text { Test } 1 /\end{array}$ & Trace Test $1 /$ \\
\hline $\begin{array}{l}\text { Sample period } \\
\mathrm{e}=\text { exchange rate measure used }\end{array}$ & 1988:Q1-2000:Q2 & & & \\
\hline 3. NEER, export weighted & $\mathrm{P}=0.6 \mathrm{ulc}+0.35 \mathrm{e}+0.5 \mathrm{p}^{*}$ & 4 & $29.22^{*}$ & $60.87^{* *}$ \\
\hline 3a. Above eqn restricted 2/ & $\mathrm{P}=0.65 \mathrm{ulc}+0.35\left(\mathrm{e}+\mathrm{p}^{*}\right)$ & 4 & 0.0647 & \\
\hline 4. NEER, import weighted & $\mathrm{P}=0.52 \mathrm{ulc}+0.3 \mathrm{e}+0.8 \mathrm{p}^{*}$ & 4 & $43.64^{* *}$ & $77.14^{* *}$ \\
\hline 4a. Above eqn restricted $2 /$ & $\mathrm{P}=0.67 \mathrm{ulc}+0.33\left(\mathrm{e}+\mathrm{p}^{*}\right)$ & 4 & 7.258 & \\
\hline $\begin{array}{l}\text { 4b. Above eqn, tariff adjustcd, } \\
\text { restricted } 2 /\end{array}$ & $\mathrm{P}=0.86 \mathrm{ulc}+0.14\left(\mathrm{e}^{+} \mathrm{p}^{*}(1+\mathrm{t})\right)$ & 3 & 2.751 & \\
\hline
\end{tabular}

$1 / *=$ significant at the 5 percent level. $* *=$ significant at the 1 percent level.

$2 /$ Test statistic displayed in the maximum eigenvalue test column is the likelihood-ratio $\left(\chi^{2}\right)$ test of the null hypothesis that the restriction holds. The significance level in footnote 1 still applies. 
Table 3: Error-Correction Models Using Equation 4a as Long-Run Relation 1/

Sample Period: 1988:Q2-2000:Q2 (t-values in parentheses)

(1)

(2)

(3)

\begin{tabular}{|c|c|c|c|}
\hline D (nonfood CPI), first lag & $\begin{array}{l}0.156 \\
(1.98)\end{array}$ & $\begin{array}{l}0.216 \\
(2.51)\end{array}$ & $\begin{array}{l}0.225 \\
(2.53)\end{array}$ \\
\hline Cointegrating vector, first lag & $\begin{array}{c}-0.226 \\
(-6.67)\end{array}$ & $\begin{array}{l}-0.21 \\
(-5.38)\end{array}$ & $\begin{array}{l}-0.213 \\
(-5.26)\end{array}$ \\
\hline D (domestic oil prices), first Iag & $\begin{array}{l}0.025 \\
(4.37)\end{array}$ & $\begin{array}{l}0.027 \\
(4.2)\end{array}$ & $\begin{array}{l}0.026 \\
(4.15)\end{array}$ \\
\hline D (imported-weighted neer) & $\begin{array}{l}0.136 \\
(5.08)\end{array}$ & $\begin{array}{l}0.137 \\
(4.76)\end{array}$ & $\begin{array}{l}0.142 \\
(4.46)\end{array}$ \\
\hline Second lag & $\begin{array}{l}0.087 \\
(3.36)\end{array}$ & $\begin{array}{l}0.081 \\
(2.81)\end{array}$ & $\begin{array}{l}0.071 \\
(2.13)\end{array}$ \\
\hline Non-agricultural output gap & $\begin{array}{l}0.068 \\
(1.7)\end{array}$ & $\begin{array}{l}0.104 \\
(1.06)\end{array}$ & $\begin{array}{l}0.134 \\
(1.36)\end{array}$ \\
\hline First lag & & $\begin{array}{l}-0.167 \\
(-1.39)\end{array}$ & $\begin{array}{l}-0.205 \\
(-1.64)\end{array}$ \\
\hline Second lag & & $\begin{array}{l}0.126 \\
(1.66)\end{array}$ & $\begin{array}{l}0.134 \\
(1.63)\end{array}$ \\
\hline D (unit labor cost) & $\begin{array}{l}0.101 \\
(5.74)\end{array}$ & $\begin{array}{l}0.091 \\
(4.33)\end{array}$ & $\begin{array}{l}0.101 \\
(4.81)\end{array}$ \\
\hline First lag & $\begin{array}{l}-0.11 \\
(-4.94)\end{array}$ & $\begin{array}{l}-0.116 \\
(-4.9)\end{array}$ & $\begin{array}{l}-0.117 \\
(-4.72)\end{array}$ \\
\hline Second lag & $\begin{array}{c}-0.069 \\
(-3.64)\end{array}$ & $\begin{array}{c}-0.063 \\
(-3.21)\end{array}$ & $\begin{array}{l}-0.066 \\
(-3.12)\end{array}$ \\
\hline D (foreign prices, import-weighted) & $\begin{array}{l}-0.78 \\
(-2.25)\end{array}$ & $\begin{array}{l}-0.711 \\
(-1.94)\end{array}$ & $\begin{array}{l}-0.777 \\
(-1.81)\end{array}$ \\
\hline D (T-bill rate) & & & $\begin{array}{l}-0.001 \\
(-0.07)\end{array}$ \\
\hline First lag & & & $\begin{array}{l}0.001 \\
(0.11)\end{array}$ \\
\hline Second lag & & & $\begin{array}{l}0.002 \\
(0.24)\end{array}$ \\
\hline Third lag & & & $\begin{array}{l}0.001 \\
(0.15)\end{array}$ \\
\hline D (reserve money) & & $\begin{array}{l}0.018 \\
(1.1)\end{array}$ & \\
\hline First lag & & $\begin{array}{l}-0.001 \\
(-0.09)\end{array}$ & \\
\hline Second lag & & $\begin{array}{l}0.003 \\
(0.18)\end{array}$ & \\
\hline Third lag & & $\begin{array}{l}0.01 \\
(0.55)\end{array}$ & \\
\hline Constant & $\begin{array}{l}0.342 \\
(6.97)\end{array}$ & $\begin{array}{l}0.313 \\
(5.68)\end{array}$ & $\begin{array}{l}0.324 \\
(5.55)\end{array}$ \\
\hline R-squared (adjusted) & 0.879 & 0.899 & 0.893 \\
\hline F-test (for regression) & $19.53^{* *}$ & $13.55^{* *}$ & $12.78^{* *}$ \\
\hline F-test (for residual autocorrelation) & 0.697 & 0.682 & 0.835 \\
\hline Chi-squared test (for normality of the residuals) & 3.57 & 1.38 & 1.80 \\
\hline F-test (for functional form) & 2.039 & 1.739 & 2.664 \\
\hline
\end{tabular}

1/ The models also include seasonal factors. The cointegrating vector is $\mathrm{P}-0.67$ ulc $-0.33 \mathrm{e}-0.33 \mathrm{p}^{*}$ 


\section{References}

De Brouwer and Ericsson. (1995). "Modeling inflation in Australia." Board of Governors of the Federal Reserve System International Finance Discussion Papers, No. 530.

Debelle, G. and C. Lim. (1998). "Preliminary considerations of an inflation targeting framework for the Philippines." IMF working paper WP/98/39.

Guinigundo, D. (1999). "Problems and issues on inflation targeting: the case of the Philippines." Paper presented at the Conference on "Framework for monetary policy in postcrisis Asia: Policy options and inflation targeting," held on Dec. 8-10, 1999 in Cebu, Philippines.

Schaechter, A., M.R. Stone and M. Zelmer. (2000). Adopting Inflation Targeting: Practical Issues for Emerging Market Countries. IMF Occasional Paper No. 202.

Rodlauer, M., et. al. (2000). Philippines: Toward Sustainable and Rapid Growth, Recent Developments and the Agenda Ahead. IMF Occasional Paper No. 187. 


\section{Further Technical Details}

Long-Run Results With the Overall Consumer Price Index

\begin{tabular}{|l|l|l|l|l|l|}
\hline & Estimated cointegrating vector & $\begin{array}{l}\text { ECM } \\
\text { coef }\end{array}$ & Lags & $\begin{array}{l}\text { Maximum } \\
\text { eigenvalue } \\
\text { test } 1 /\end{array}$ & $\begin{array}{l}\text { Trace test } \\
1 /\end{array}$ \\
\hline Sample period & $1988 \mathrm{Q} 1-2000 \mathrm{Q} 2$ & $\ldots$ & & & \\
\hline Exchange rate used & & & & & \\
\hline 1. Bilateral exchange, US\$ & $\mathrm{P}=-0.58 \mathrm{ulc}+0.13 \mathrm{e}+4.41 \mathrm{p}^{*}$ & -0.14 & 4 & 18.5 & 40.1 \\
\hline 2. NEER, tariff adjusted & $\mathrm{P}=0.46 \mathrm{ulc}-0.31\left(\mathrm{c}+\mathrm{p}^{*}\right)$ & -0.13 & 4 & $38.02^{* *}$ & $54.98^{* *}$ \\
\hline 3. NEER & $\mathrm{P}=0.25 \mathrm{ulc}+0.4 \mathrm{p}^{*}+0.34 \mathrm{e}$ & -0.09 & 4 & 26.24 & $48.75^{*}$ \\
\hline 4. NEER, export weighted & $\mathrm{P}=-0.44 \mathrm{ulc}+0.32 \mathrm{e}+3.43 \mathrm{p}^{*}$ & -0.10 & 4 & $31.51^{*}$ & $61.53^{* *}$ \\
\hline 5. NEER, import weighted & $\mathrm{P}=0.23 \mathrm{ulc}+0.12 \mathrm{e}+1.64 \mathrm{p}^{*}$ & -0.39 & 4 & $32.95^{* *}$ & $59.37^{* *}$ \\
\hline $\begin{array}{l}\text { 6. NEER, import-weighted, } \\
\text { tariff-adjusted }\end{array}$ & $\mathrm{P}=0.97 \mathrm{ulc}-1.2\left(\mathrm{e}+\mathrm{p}^{*}(1+\mathrm{t})\right)$ & -0.07 & 4 & $38.11^{* *}$ & $55.81^{* *}$ \\
\hline
\end{tabular}

$1 / *=$ significant at the 5 percent level. ** = significant at the 1 percent level.

\section{Tests for weak exogeneity}

Results from testing for weak exogeneity indicate that the unrestricted model from Equation 4 in Table 2 can be reduced down to a single equation model, as the feedback effects from the cointegrating vector only enter into the nonfood inflation equation.

Tests from the restricted model (Equation 4a in Table 2) reject weak exogeneity for all variables except for the unit labor cost. Results from the error-correction model using either the restricted or unrestricted cointegrating vector are quite similar in magnitudes and significance of the coefficients, suggesting that the loss in efficiency from reducing the restricted model to a single equation is limited.

\section{Chi-Squared Test}

(Degrees of freedom in parentheses)

\begin{tabular}{llllll}
\hline & $\begin{array}{l}\text { Joint test } \\
\text { (Neer, } \mathrm{p}^{*}, \\
\text { and ulc) }\end{array}$ & $\begin{array}{l}\text { Non-food } \\
\text { inflation }\end{array}$ & $\begin{array}{l}\text { Import- } \\
\text { weighted } \\
\text { NEER }\end{array}$ & $\begin{array}{l}\text { Import-weighted } \\
\text { foreign prices } \mathrm{p}^{*}\end{array}$ & Unit labor cost (ulc) \\
\hline Unrestricted & 3.46 & $9.73^{* *}$ & 2.604 & 2.05 & 0.12 \\
& $(3)$ & $(1)$ & $(1)$ & $(1)$ & $(1)$ \\
Restricted & $17.659^{* *}$ & $11.739^{* *}$ & $12.667^{*}$ & $13.74^{* *}$ & 8.419 \\
& $(6)$ & $(4)$ & $(4)$ & $(4)$ & $(4)$ \\
\hline
\end{tabular}

** Weak exogeneity rejected at the $1 \%$ significance level.

* Weak exogeneity rejected at the $5 \%$ significance level. 
Tests for Unit Roots

\begin{tabular}{|c|c|c|c|c|c|c|c|c|c|c|c|c|c|}
\hline Variable & $\begin{array}{l}\text { Order of } \\
\text { Integration }\end{array}$ & I(1) Test & $\begin{array}{l}\text { Estimated } \\
\text { Coefficient }\end{array}$ & $\begin{array}{c}\text { Type } \\
1 /\end{array}$ & Lags & $\mathrm{I}(2)$ Test & $\begin{array}{c}\text { Estimated } \\
\text { Coefficient }\end{array}$ & $\begin{array}{c}\text { Type } \\
1 /\end{array}$ & Lags & I(3) Test & $\begin{array}{l}\text { Estimated } \\
\text { Coefficient }\end{array}$ & $\begin{array}{c}\text { Type } \\
1 /\end{array}$ & Lags \\
\hline Nonfood CPI & $\mathrm{I}(1)$ & -0.11 & -0.03 & $\mathbf{T}$ & 2 & $-3.2 *$ & $(-0.39)$ & $\mathrm{C}$ & 1 & & & & \\
\hline Unit Labor Cost & $\mathrm{I}(0)$ or $\mathrm{I}(1)$ & $-3.33 *$ & $(-0.06)$ & $\mathrm{C}$ & 7 & $-3.08 *$ & $(-0.95)$ & $\mathrm{C}$ & 3 & & & & \\
\hline NEER, export weighted & $\mathrm{I}(0)$ or $\mathrm{I}(1)$ & $-3.23 *$ & $(-0.06)$ & $\mathrm{C}$ & 5 & $-6.17 * *$ & $(-0.71)$ & $\mathrm{C}$ & 0 & & & & \\
\hline Foreign prices, export weighted & $\mathrm{I}(2)$ & 1.5 & $(0.00)$ & $\mathrm{N}$ & 8 & -0.92 & $(-0.03)$ & $\mathrm{N}$ & 7 & $-2.69 * *$ & $(-1.48)$ & $N$ & 6 \\
\hline 91-day $\mathrm{T}-$ bill rate & $\mathrm{I}(1)$ & -2.39 & $(-0.14)$ & $\mathrm{N}$ & 1 & $-7.04 * *$ & $(-0.83)$ & $\mathrm{N}$ & 0 & & & & \\
\hline Non-agricultural output gap & $\mathrm{I}(1)$ & -2.37 & $(-0.25)$ & $\mathrm{N}$ & 8 & $-4.54 * *$ & $(-1.35)$ & $\mathrm{N}$ & 7 & & & & \\
\hline Reserve money & $\mathrm{I}(2)$ & -2.45 & $(-0.07)$ & $\mathrm{C}$ & 8 & -0.88 & $(-0.24)$ & $\mathrm{N}$ & 7 & $-5.81 * *$ & $(-7.26)$ & $\mathrm{N}$ & 6 \\
\hline NEER, import-weighted & $\mathrm{I}(1)$ & $-3.46 *$ & $(-0.07)$ & $\mathrm{C}$ & 5 & $-6.22 * *$ & $(-0.72)$ & $\mathrm{C}$ & 0 & & & & \\
\hline Forcign prices, import weighted & $\mathrm{I}(1)$ & $2.84 \quad 2 /$ & $(0.00)$ & $\mathrm{N}$ & 1 & $-3.45 *$ & $(-0.3)$ & $\mathrm{C}$ & 0 & $-5.68 * *$ & $(-1.88)$ & $\mathrm{N}$ & 3 \\
\hline Tariff-adjusted foreign prices, import-weighted & $\mathrm{I}(1)$ & $-4.09 * *$ & $(-0.15)$ & $\mathrm{C}$ & 5 & $-6.72 * *$ & $(-0.79)$ & $\mathrm{C}$ & 1 & & & & \\
\hline Tariff-adjusted foreign prices & $\mathrm{I}(1)$ & -2.56 & $(-0.08)$ & $\mathrm{T}$ & 1 & $-6.21 * *$ & $(-0.71)$ & $\mathrm{N}$ & 0 & & & & \\
\hline Bilateral exchange rate, pesos/U.S. dollar & $\mathrm{I}(1)$ & -2.55 & $(-0.04)$ & $\mathrm{C}$ & 1 & $-5.43 * *$ & $(-0.60)$ & $\mathrm{C}$ & 0 & & & & \\
\hline CPI U.S. & $\mathrm{I}(2)$ & -1.76 & $(-0.004)$ & $\mathrm{C}$ & 3 & -2.72 & $(-0.37)$ & $\mathrm{C}$ & 2 & $-12.23 * *$ & $(-1.88)$ & & \\
\hline Oil & $\mathrm{I}(1)$ & -2.93 & $(-0.3)$ & $\mathrm{T}$ & 3 & $-8.01 * *$ & $(-1.18)$ & $\mathrm{N}$ & 1 & & & & \\
\hline NEER & $\mathrm{I}(0)$ & $-3.77^{* *}$ & $(-0.098)$ & $\mathrm{C}$ & 5 & $-6.04 * *$ & $(-0.69)$ & $\mathrm{C}$ & 0 & & & & \\
\hline CPI world & $\mathrm{I}(2)$ & $0.08 \quad 2 /$ & $(0.00)$ & $\mathrm{N}$ & 9 & -0.85 & $(-0.03)$ & $\mathbf{N}$ & 8 & $-3.39 * *$ & $(-1.96)$ & $\mathbf{N}$ & \\
\hline
\end{tabular}

1/ The type of Augmented Dickey Fuller (ADF) equation used, i.e. with trend $(T)$, constant (C), and none $(N)$.

2/ Positive ADF statistic indicates unit root.

* Indicates 5\% significance level.

**Indicates $1 \%$ significance level. 


\section{Data Sources and Definitions}

Variable

Definition

Nominal effective exchange rate (NEER)

Nonfood CPI

NEER

CPI world

Tariff adjusted

NEER(export-wcighted)

Forcign prices

NEER(import-weighted)

Foreign prices

Tariff adjusted

Unit Labor Cost

Oil prices

Non-agricultural output gap

\section{Reserve money}

91-day T-bill rate

Pesos/U.S. dollar
Matched to trading partners with NEER measure

CPI world * (1+average import tariff rate $)$

1999-2000 export weights, top 20 trading partners

Matched to trading partners with export-weighted NEER measure

1999-2000 import weights, top 20 trading partners

Matched to trading partners as import-weighted NEER measure

Foreign prices *(1+average import tariff rate)

Index. Daily minimum wage

*number of business days in a quarter

*number of people employed/Real output

World oil prices (Dubai), converted into pesos using the average exchange rate

Non-agricultural output-potential non-agricultural output (calculated using the Hodrick-Prescott filter)/Nonagricultural output

end period

period average

period average

\section{Source}

National Statistics Office (NSO)

Effcctive Exchange Rate Facility (IMF)

Based on International Financial Statistics data (IFS, IMF)

Tariff rate data from Government Financial

Statistics (GFS, IMF) and authorities

Minimum wage data from the authorities

World Economic Outlook (WEO, IMF) and IFS

Output data from the authorities

Data from the authorities

IFS

IFS 